\title{
PEMBINAAN MASYARAKAT DALAM PERBAIKAN SANITASI LINGKUNGAN
}

\section{COMMUNITY DEVELOPMENT IN IMPROVEMENT OF ENVIRONMENTAL SANITATION}

\author{
Nursalim $^{1)}$, Meri Meliyanti Saputri ${ }^{2)}$, Nurlinda ${ }^{3)}$, Safrul Muhammad ${ }^{4)}$, Jumawati ${ }^{5)}$, \\ ${\text { Irfan } \mathbf{J}^{6)} \text {, Nastia }}^{\left.7^{*}\right)}$, Muhammad Hidayatullah ${ }^{8)}$ \\ 1,2,3 Mahasiswa Program Studi Ilmu Pemerintahan \\ ${ }^{4,5,6}$ Mahasiswa Program Studi Ilmu Komunikasi \\ ${ }^{7}$ Dosen Fakultas Ilmu Sosial dan Ilmu Politik Program Studi Ilmu Pemerintahan, \\ ${ }^{8}$ Dosen Fakultas Ilmu Sosial dan Ilmu Politik Program Studi Ilmu Komunikasi \\ Universitas Muhammadiyah Buton \\ Email: nastiatia567@gmail.com
}

\begin{abstract}
Abstrak: Program pengabdian masyarakat ini dilakukan di Desa Mopaano Kecamatan Lasalimu Selatan Kabupaten Buton. Beberapa masalah pokok yang menjadi masalah di Desa Mopaano Kecamatan Lasalimu Selatan Kabupaten Buton sekaligus hal-hal yang perlu dilakukan pemberdayaan, yakni belum optimalnya pengetahuan masyarakat mengenai pentingnya sanitasi lingkungan dan belum optimalnya sosialisasi kepada masyarakat perihal bagaimana menciptakan dan meningkatkan lingkungan yang sehat. Hasil kegiatan PKM ini dapat dideskripsikan melalui peran modal sosial masyarakat sebagai bentuk pengetahuan lokal, dapat dimanfaatkan sebagai sarana mensosialisasikan pentingnya kesadaran akan sanitasi lingkungan. Proses meningkatkan pengetahuan masyarakat dalam perbaikan sanitasi lingkungan dilaksanakan melalui tiga pendekatan yaitu sosialisasi, pendampingan dan perencanaan pembuatan tong sampah dan pembuatan jamban.
\end{abstract}

Kata kunci: Sanitasi Lingkungan, Modal Sosial

Abstract: This community service program is carried out in Mopaano Village, Lasalimu Selatan District, Buton Regency. Some main problems that become a problem in Mopaano Village, Lasalimu Subdistrict, South Buton District, are at the same time things that need to be done empowering, namely not yet optimal public knowledge about the importance of Environmental Sanitation and not yet optimal socialization to the public about how to create and improve a healthy environment. The results of this PKM activity can be described through the role of social capital as a form of local knowledge, can be used as a means of socializing the importance of environmental sanitation awareness. The process of increasing community knowledge in improving environmental sanitation is carried out through three approaches, namely socialization, assistance and planning for making garbage cans and making latrines.

Keywords: Environmental Sanitation and Social Capital 


\section{INTEGRITAS : Jurnal Pengabdian}

Vol 4, No 1, Juli 2020

ISSN 2580 - 7978 (cetak) ISSN 2615 - 0794 (online)

\section{PENDAHULUAN}

Sanitasi disini adalah upaya yang dilakukan untuk merubah perilaku budaya hidup bersih dan sehat dengan tidak buang air besar sembarangan, mencuci tangan pakai sabun, mengelola air minum dan makanan yang aman, mengelola sampah rumah tangga dengan aman dan mengelola limbah cair rumah tangga dengan aman.

Lingkungan juga bisa diartikan sebagai segala sesuatu yang terdapat di sekitar manusia kemudian tinggal bersama dan saling mempengaruhi bagi perkembangan kehidupan manusia. Jadi pengertian sanitasi lingkungan adalah status kesehatan suatu lingkungan yang mencakup perumahan, pembuangan ketoran, penyediaan air bersih dan sebagainya (Notoatmodjo. 2003).

Sanitasi lingkungan merupakan suatu usaha untuk mencapai lingkungan sehat melalui pengendalian faktor lingkungan fisik, khususnya hal-hal yang memiliki dampak merusak perkembangan fisik kesehatan dan kelangsungan hidup manusia. Sanitasi lingkungan mempunyai kedudukan yang paling penting dalam kehidupan sehari-hari, karena berpengaruh terhadap kesehatan seseorang dan masyarakat. Sanitasi lingkungan dapat mencerminkan tata cara hidup dari masyarakat tersebut. Untuk mendapatkan kondisi sanitasi lingkungan yang baik sangat bergantung dari tata cara dan perilaku masyarakat di dalam memelihara kualitas sanitasi lingkungannya.

Program perilaku hidup bersih dan sehat adalah salah satu upaya promosikesehatan yang bertujuan agar setiap orangdapat tinggal di lingkungan yang bersih dan sehat dengan menciptakan suatu kondisi yang kondusif bagi perorangan, keluarga, kelompok dan masyarakat. Hal ini bertujuan untuk meningkatkan pengetahuan, sikap dan perilaku agar dapat menerapkan cara-cara hidup sehat dalam rangka menjaga, memelihara, dan meningkatkan kesehatan (Rahman dan Patilaiya, 2018).

Dari defenisi diatas, tampak bahwa sanitasi lingkungan ditujukan untuk memenuhi persyaratan-persyaratan lingkungan yang sehat dan nyaman. 


\section{INTEGRITAS : Jurnal Pengabdian}

Vol 4, No 1, Juli 2020

ISSN $2580-7978$ (cetak) ISSN $2615-0794$ (online)

Lingkungan yang sanitasinya buruk dapat menjadi sumber berbagai macam penyakit yang dapat mengganggu kesehatan manusia. Pada akhirnya jika kesehatan terganggu, maka kesejahteraan juga akan berkurang.

Berdasarkan observasi yang dilakukan oleh tim pengabdian kepada masyarakat (PKM) Fakultas Ilmu Sosial dan Ilmu Politik Universitas Muhammadiyah Buton di Desa Mopaano Kecamatan Lasalimu Selatan, kesadaran masyarakat terhadap lingkungan sangatlah minim, berdasarkan hal tersebut dapat diprediksi bahwa masyarakat masih belum peduli terhadap kebersihan lingkungan sekitarnya. Kebanyakan dari masyarakat berfikir secara persial dan hanya ingin menguntungkan diri sendiri, seperti masalah pembuangan sampah yang tidak pada tempatnya, pembuangan limbah rumah tangga dan lain-lain. Kasus-kasus yang menyangkut masalah kebersihan setiap tahunnya selalu meningkat, dan mengakibatkan keadaan yang merugikan seperti banyaknya sampah yang menumpuk di titik-titik tertentu dan saluran air yang bisa menyebabkan banjir karena meluapnya air yang tidak tertampung, untuk itu kepedulian masyarakat sangat dibutuhkan tidak hanya pemerintah setempat yang harus menanggungnya.

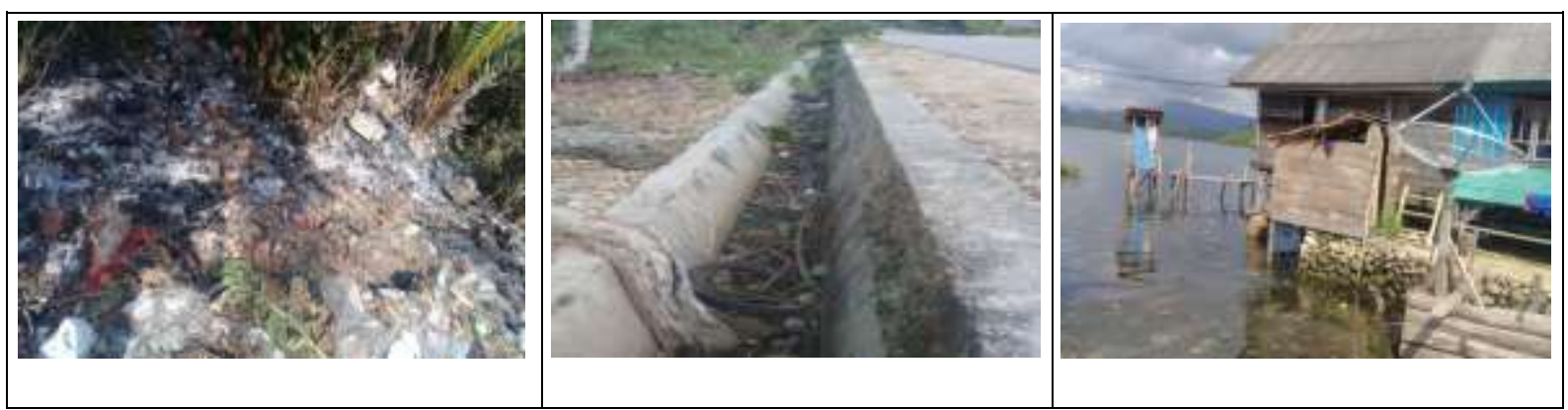

Gambar 1. Tempat Pembuangan Sampah, Saluran Drainase dan Kondisi jamban Desa Mopaano

Sanitasi lingkungan seperti gambar diatas dapat mengundang munculnya berbagai penyakit, dapat dilihat dengan masih adanya masyarakat yang belum mempraktekan perilaku hidup sehat, seperti membuang sampah sembarangan, fasilitas jamban rumah warga yang belum memadai. 


\section{INTEGRITAS : Jurnal Pengabdian}

Kesadaran masyarakat dalam hal ini menjadi penting, karena kesadaran masyarakat adalah proses yang diawali dari adanya rasa memiliki, yaitu rasa memiliki lingkungan sekitar yang akan memicu rasa tanggung jawab. Rasa tanggung jawab ini akan menghasilkan kesadaran warga bahwa tugas untuk menjaga lingkungan bukan hanya kewajiban pemerintah saja tapi juga warganya. Mengingat tentang kesadaran tersebut, perlu di ketahui juga bahwa bencana seperti banjir, longsor, dan meluapnya air dikarenakan ketidak pedulian masyarakat itu sendiri.

Kegiatan PKM ini dilaksanakan oleh dosen dan mahasiwa Fakultas Ilmu Sosial dan Ilmu Politik Universitas Muhammadiyah Buton. Kegiatan pengabdian ini tidak hanya sebagai perwujudan tanggung jawab dosen untuk melaksanakan tanggungjawab dalam hal tridharma perguruan tinggi yang dilaksanakan rutin setiap tahun pada masyarakat, melainkan juga sebagai sebuah kegiatan yang memberikan pengalaman kepada mahasiswa untuk belajar dan menerapkan keterampilan sesuai bidang keahlian yang di pelajari untuk di terapkan kepada masyarakat. Kegiatan ini tentunya akan menambah wawasan sekaligus melengkapi keterampilan dosen dan mahasiswa.

Dalam sejumlah observasi yang dilakukan dapat disimpulkan beberapa masalah pokok yang menjadi masalah di Desa Mopaano Kecamatan Lasalimu selatan Kabupaten Buton sekaligus hal-hal yang perlu dilakukan pemberdayaan, yakni sebagai berikut:

1. Belum optimalnya pengetahuan masyarakat mengenai pentingnya Sanitasi Lingkungan.

2. Belum optimalnya sosialisasi kepada masyarakat perihal bagaimana menciptakan dan meningkatkan lingkungan yang sehat. 


\section{INTEGRITAS : Jurnal Pengabdian}

\section{METODE PELAKSANAAN}

Pengabdian masyarakat ini dilaksanakan melalui pendekatan modal sosial, sebab hal ini lebih mudah ditemukan dalam masyarakat yang lebih menonjol dalam ikatan budaya, kekerabatan dan lingkungan. Dengan begitu, pendekatan modal sosial memungkinkan adanya ikatan timbal balik dari dan kepada masyarakat lokal tersebut. Modal sosial sebagai perekat sosial (social glue) pada komunitas masyarakat. Oleh karena itu, modal sosial tersebut akan sangat ditentukan sebagai akumulasi dari beragam tipe dari aspek sosial, psikologi, budaya, kelembagaan, dan aset yang tidak terlihat (intangible) yang mempengaruhi perilaku kerjasama (Arya Maulana Wijaya et al., 2019). Dengan deskripsi modal sosial seperti diatas, dipercaya bahwa pendekatan seperti itu dapat dijadikan salah satu sarana untuk mensosialisasikan Sanitasi Lingkungan kepada masyarakat. Melalui, kondisi masyarakat Desa Mopaano yang masih memegang erat kehidupan dan pengalaman budaya, serta kehidupan gotong royong masyarakatnya. Maka pendekatan budaya dan komunitas, memungkinkan adanya kolaborasi antara input kebijakan.

Modal sosial dimaksud sebagai metode pelaksanaan pengabdian masyarakat disini dapat diamati dalam pembentukan dan penguatan kelembagaan masyarakat lokal sadar lingkungan. Melalui tahapan Observasi, Wawancara Tokoh, dan Sosialisasi.

\section{HASIL DAN PEMBAHASAN}

Tahapan Kegiatan Pengabdian Kepada Masyarakat (PKM) yang dilakukan adalah sebagai berikut:

\section{Sosialisasi}

Tahap sosialisasi program Sanitasi Lingkungan dilaksanakan di dibalai pertemuan Desa Mopaano, pertemuan dihadiri oleh kepala Desa, Kepala Dusun, dan masyarakat Desa Mopaano. Kemudian selain sosialisasi secara langsung. 


\section{INTEGRITAS : Jurnal Pengabdian}

Sosialisasi tentang pentingnya Sanitasi Lingkungan yaitu stop buang sampah yang bukan pada tempatnya, jangan buang air besar sembarangan(membuat jaban dalam rumah). Kemudian pada tahap sosialisasi diberikan pemahaman tentang efek samping dari buang sampah yang bukan pada tempatnya dapat menimbulkan bau yang tak sedap untuk dihirup, menyebabkan wabah penyakit yaitu penyakit diare serta dapat menimbulkan banjir yang dikarenakan tersumbatnya saluran drainase, seperti pada gambar berikut:

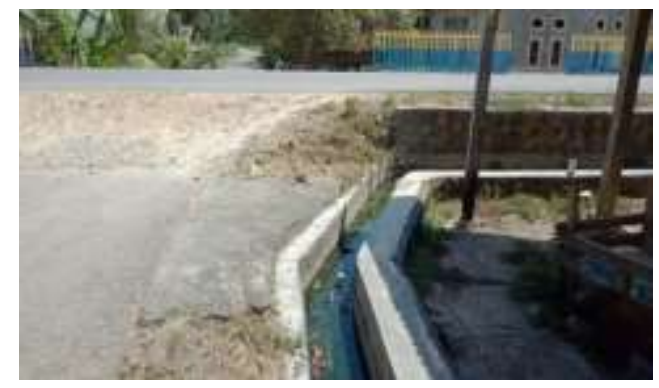

Gambar 2. Saluran Drainase yang tersumbat di Desa Mopaano

Efek buang air besar di sembarang tempat juga dapat menimbulkan berbagai penyakit berbahaya yaitu salah satunya penyakit ekoli (penyebab diare). Sehingga dari sosialisasi ini dapat membangun kesadaran masyarakat agar tidak buang air besar di sembarang tempat dan menjaga lingkungannya tetap bersih atau masyarakat dapat berperilaku budaya hidup bersih dan sehat.

\section{Pendampingan}

Setelah diadakannya sosialisasi dilanjutkan dengan metode pendampingan yang mana kegiatan ini dilakukan pada masing-masing dusun dengan didampingi. Oleh Kepala Desa Mopaano dan kepala-kepala dusun, mereka semua memberi penjelasan tentang tujuan diadakannya program sanitasi lingkungan yaitu agar terjadi perubahan prilaku sebagian masyarakat dari buang sampah yang bukan pada tempatnya serta pemahaman jangan buang air besar di sembarang tempat dengan menyentuh pola pikir, prilaku dan kebiasaan. Tujuan dilakukannya pendampingan untuk memotivasi masyarakat agar dapat merubah perilaku. Bila perilaku masyarakat sudah berubah maka anggota masyarakat tersebut akan 


\section{INTEGRITAS : Jurnal Pengabdian}

Vol 4, No 1, Juli 2020

ISSN $2580-7978$ (cetak) ISSN $2615-0794$ (online)

membuang sampah pada tempat yang telah disediakan dan akan memiliki jamban di dalam lingkungan rumah sendiri. Perilaku yang bersih dan sehat dengan tidak mengotori lingkungan sekitarnya dengan menyentuh pola pikir, perilaku dan kebiasaan masyarakat.

\section{Perencanaan Pembuatan Tong Sampah dan Pembuatan Jamban}

Setelah diadakan pendampingan maka kegiatan selanjutnya adalah rencana tindak lanjut masyarakat untuk melakukan perubahan hidup sehat dan bersih yaitu dengan cara masyarakat tidak dibolehkan lagi membuang sampah yang bukan pada tempatnya dan buang air besar di sembarang tempat sehingga masyarakat diharuskan untuk membuat tong sampah dan jamban pribadi di masing-masing rumahnya. Semua masyarakat diharuskan untuk membuat dan menaruh tong sampah didepan rumah disetiap dusun agar setiap pagi dan sore hari petugas kebersihan lingkungan Desa Mopaano datang mengangkat sampah dan membuangnya pada tempat yang telah disediakan oleh pihak pemerintah desa.

Setelah itu kita bersama-sama mencari solusi rencana tindak lanjut dalam menentukan berapa biaya penyediaan tong sampah setelah itu membahas pembuatan jamban secara gotong royong. Bagi yang belum mampu untuk membuat WC dirumah kita memberikan solusi untuk merehap atau membersihkan WC umum secara gotong royong yang telah disediakan oleh pemerintah agar layak untuk digunakan bagi masyarakat yang belum memiliki WC dirumah.

\section{KESIMPULAN}

Program pengabdian masyarakat ini menyimpulkan bahwa peran modalsosial dapat digunakan untuk masyarakat dalam bentuk pengetahuan lokal, yang kemudian dapat dimanfaatkan sebagai sarana mensosialisasikan pentingnya kesadaran sanitasi lingkungan. Proses meningkatkan pengetahuan masyarakat dalam perbaikan sanitasi lingkungan dilaksanakan melalui: sosialisai tentang sanitasi lingkungan kepada masyarakat, pendampingan dan Perencanaan Pembuatan Tong Sampah dan Pembuatan Jamban. 
Dalam pelaksanaanya, pendekatan ini dipengaruhi oleh pengetahuan masyarakat, sarana dan prasarana pendukung program serta minimnya dukungan kesadaran terhadap dampak sanitasi lingkungan pada pendidikan masyarakat setempat.

\section{DAFTAR PUSTAKA}

Arya Maulana Wijaya, A., Sadat, A., Azhar Sa, L., Suherman, A., Fajar Maulana, H., \& Rizal Ardiansah Putra, M. (2019). Pemanfaatan Modal Sosial Dalam Penguatan Program Desa Tangguh Bencana. Jurnal Pengabdian Kepada Masyarakat MEMBANGUN NEGERI, 2(1), 1-13.

Notoatmodjo, Soekidjo. 2003. Pendidikan Dan Perilaku Kesehatan. Rineka Cipta. Jakarta.

Mardikanto, T dan Soebiato, P. 2012. Pemberdayaan Masyarakat Dalam Perspektif Kebijakan Publik. Bandung : Alfabeta.

Rahman, H., \& Patilaiya, H. La. (2018). Pemberdayaan Masyarakat Melalui Penyuluhan Perilaku Hidup Bersih dan Sehat untuk Meningkatkan Kualitas Kesehatan Masyarakat. JPPM (Jurnal Pengabdian Dan Pemberdayaan Masyarakat), 2(2), 251. https://doi.org/10.30595/jppm.v2i2.2512 